\title{
ANALISIS PUTUSAN MA ATAS KASASI PUTUSAN PN. TUBAN NOMOR 25/PDT. G/2013/PN. TUBAN TENTANG PERJANJIAN PERKAWINAN
}

\author{
Khalida Hayasinana, Agus Sarono, Budi Ispriyarso \\ Program Studi Magister Kenotariatan, \\ Fakultas Hukum, Universitas Diponegoro \\ Email : khayasinana@gmail.com
}

\begin{abstract}
Analysis of Supreme Court decisions on cassation of PN.Tuban Decision Number 25/Pdt.G/2013/PN.Tuban regarding Marriage Agreements, discussing the background of marital dispute agreements and analysis of decisions on Marriage Agreements. This type of research is juridical normative using reports, because it will conceptualize the law as what is written in the regulations by analyzing decisions, specifications descriptive analytical research, data collection methods using literature and case studies, data analysis methods using qualitative analysis methods. It is known that the implementation of the marriage agreement made between the Plaintiff and Defendant $\mathrm{I}$ is not in accordance with the contents of the agreement and has never been registered at the Office of Population and Civil Registry and the Registrar's Office of the District Court. In the Supreme Court decision on appeal of PN.Tuban Number 25/Pdt.G/2013/PN.Tuban, the Panel of Judges decided to reject Defendant I's exception to the fullest, in the main case to grant some of the plaintiff's claim and sentence Defendant I, Defendant II, and Co-Defendant to be requested in this decision. Decisions of the Panel of Judges based on Law Number 1 of 1974 concerning Marriage Article 29 and Article 35 and Civil Code Article 147, Article 149, and Article 152.
\end{abstract}

Keywords : verdict;cassation; agreement; marriage

\begin{abstract}
Abstrak
Analisis putusan MA atas kasasi putusan PN.Tuban Nomor 25/Pdt.G/2013/PN.Tuban tentang Perjanjian Perkawinan, membahas mengenai latar belakang terjadinya sengketa perjanjian perkawinan dan analisis putusan tentang Perjanjian Perkawinan. Jenis penelitian ini adalah yuridis normatif dengan pendekatan kasus, karena akan mengkonsepsikan hukum sebagai apa yang tertulis dalam peraturan perundang-undangan dengan menganalisis putusan, spesifikasi penelitian deskriptif analitis, metode pengumpulan data menggunakan studi pustaka dan studi dokumentasi, metode analisis data menggunakan metode analisis-kualitatif. Diketahui pelaksanaan perjanjian perkawinan yang dibuat antara Penggugat dan Tergugat I tidak sesuai dengan isi perjanjian serta tidak pernah teregister di Kantor Dinas Kependudukan dan Catatan Sipil dan Kantor Kepaniteraan Pengadilan Negeri. Dalam putusan MA atas kasasi putusan PN.Tuban Nomor 25/Pdt.G/2013/PN. Tuban, Majelis Hakim memutuskan dalam eksepsi untuk menolak eksepsi Tergugat I untuk seluruhnya, dalam pokok perkara untuk mengabulkan sebagian gugatan dari Penggugat dan menghukum Tergugat I, Tergugat II, dan Turut Tergugat untuk tunduk pada putusan ini. Putusan Majelis Hakim berdasarkan pada Undang-Undang Nomor 1 Tahun 1974 tentang Perkawinan Pasal 29 dan Pasal 35 serta KUH Perdata Pasal 147, Pasal 149, dan Pasal 152.
\end{abstract}

Kata kunci : putusan; kasasi; perjanjian; perkawinan 


\section{A. Pendahuluan}

Dalam Pasal 1 Undang-Undang Perkawinan Nomor 1 Tahun 1974 tentang perkawinan(Undang-Undang Perkawinan 1974), perkawinan ialah ikatan lahir batin seorang pria dengan seorang wanita sebagai suami-istri dengan tujuan membentuk keluarga (rumah tangga) yang bahagia dan kekal berdasarkan Ketuhanan Yang Maha Esa.(Jehani 2008). Perkawinan merupakan suatu perjanjian tertulis yang sah diantara seorang suami dan istri. Suatu perkawinan juga melahirkan permasalahan harta benda dari suami maupun istri, kekayaan yang dimaksud berupa kekayaan pribadi atau harta bawaan.(Yuliartha 2007). Calon pasangan suamiistri sebelum melangkah ke jenjang perkawinan ada kalanya membuat suatu perjanjian kawin.Isi yang diatur di dalam perjanjian kawin tergantung pada pihak calon suami maupun calon istri, asal tidak bertentangan dengan undang-undang, agama dan kepatutan atau kesusilaan. Bentuk dan isi perjanjian kawin, sebagaimana halnya dengan perjanjian pada umumnya, kepada kedua belah pihak diberikan kebebasan (sesuai dengan asas hukum "kebebasan berkontrak") karena ada prisipnya, setiap orang berhak atas kebebasan berserikat, berkumpul, dan mengeluarkan pendapat sebagaimana yang terdapat dalam Pasal 28 Undang-Undang Dasar 1945 ("UUD 1945”) dan Pasal 28E ayat (3) UUD 1945,(Undang-Undang Dasar Negara Republik Indonesia Tahun 1945, n.d.) asalkan tidak bertentangan dengan undang-undang, kesusilaan atau tidak melanggar ketertiban umum (Manjorang and Aditya 2015).

Pasangan yang hendak melangsungkan perkawinan pada umumnya sangat jarang atau bahkan tidak pernah mempermasalahkan mengenai harta masing-masing pihak atau percampuran harta yang akan terjadi setelah perkawinan. Namun semakin berkembangnya situasi dan kondisi dalam masyarakat, terutama dengan semakin banyaknya pengaruh budaya asing masuk ke Indonesia, sedikit demi sedikit merubah pola hidup dan pandangan masyarakat.(Azzam 2012) Harta masing-masing pihak maupun percampuran harta dalam perkawinan menjadi suatu permasalahan yang disoroti oleh pasangan suami-istri yang hendak melangsungkan perkawinan.

Dibuatnya perjanjian kawin sebelum perkawinan, membawa konsekuensipada calon pasangan suami isteri yaitu terpisahnya harta masing-masing pihakcalon suami-isteri dimana masing-masing berwenang mengurus danmengusahakan hartanya, sehingga apabila terjadi perceraian di antara calonsuami-isteri tersebut kelak maka mengenai harta perkawinan akan diseleaikansebagaimana diatur dalam perjanjian kawin yang telah dibuat di antara keduacalon suami-isteri tersebut. 
Perjanjian perkawinan di Indonesia mulai diperbolehkan dibuat sejak diberlakukannya KUHPerdata pada tanggal 1 Mei 1848.Dalam hal perjanjian perkawinan ini, kemudian dimuat dan dipertegas kembali dengan diundangkannya Undang-Undang Perkwinan Nomor 1 Tahun 1974. Sementara itu akibat daripada perkembangan zaman yang semakin pesat serta adanya tuntutan persamaan derajat antara laki-laki dengan wanita, menyebabkan perjanjian perkawinan tersebut lebih sering dibuat sebelum calon pasangan suami istri melangsungkan perkawinan.(Arief 2017)“Perjanjian Kawin” adalah sama seperti “perjanjian” pada umumnya, yakni kedua belah pihak diberikan kebebasan (sesuai dengan asas hukum "kebebasan berkontrak") asalkan tidak bertentangan dengan undang-undang, kesusilaan, atau tidak melanggar ketertiban umum. (Silviana 2013)Perjanjian Perkawinan merupakan suatu kesepakatan seorang laki-laki dengan seorang perempuan yang akan melangsungkan perkawinan untuk memisahkan kepemilikan harta dan utang piutang, dan kesepakatan tentang sejumlah hal penting lain pada saat mengarungi bahtera rumah tangga. Menurut Hilman Hadikusuma, kedudukan harta perkawinan sebagai modal kekayaan untuk membiayai kehidupan rumah tangga suami-istri, maka harta perkawinan itu dapat digolongkan dalam beberapa macam, sebagai berikut :

1. Harta yang diperoleh/dikuasai suami atau istri sebelum perkawinan, yaitu "harta bawaan".

2. Harta yang diperoleh/dikuasai suami atau istri secara perseorangan sebelum atau sesudah perkawinan, yaitu "harta penghasilan".

3. Harta yang diperoleh/dikuasai suami dan istri bersama-sama selama perkawinan, yaitu "harta pencaharian".

4. Harta yang diperoleh suami istri bersama ketika upacara perkawinan sebagai hadiah, yang kita sebut "hadiah perkawinan".

Berkaitan dengan definisi perjanjian perkawinan tidak dijelaskan secara eksplisit di dalam perundang-undangan, melainkan secara implisit diatur di dalam beberapa peraturan perundangundangan. Peraturan yang pertama kali mengatur perjanjian perkawinan yaitu tercantum di dalam pasal 139-154 Kitab Undang-Undang Hukum Perdata (selanjutnya disingkat KUHPerdata), kemudian dilanjutkan dengan terbitnya UndangUndang Nomor 1 Tahun 1974 Tentang Perkawinan (selanjutnya disebut UU Perkawinan) tepatnya pada Pasal 29 UU Perkawinan, dan Pasal 45-52 Instruksi Presiden Republik Indonesia Nomor 1 Tahun 1991 Tentang Penyebarluasan Kompilasi Hukum Islam (selanjutnya disebut KHI) (Instruksi Presiden 1991). Berikut persamaan dari ketiga peraturan perundang-undangan yang mengatur tentang 
perjanjian perkawinan.(Susanti 2018)Reaksi dari Inpres ini adalah dikeluarkannya Keputusan Menteri Agama Nomor 154 Tahun 1991 Tentang Pelaksanaan Instruksi Presiden Republik Indonesia Nomor 1 Tahun 1991 Tanggal 10 Juni 1991 yang berisi agar seluruh instansi Departemen Agama dan instansi pemerintah lainnya yang terkait agar menyebarluaskanKompilasi Hukum Islam dan menerapkannya dalam masalah-masalah salah satunya dibidang perkawinan.(Keputusan Menteri Agama 1991).

\section{Tabel 1}

\section{Persamaan Pengaturan Perjanjian Perkawinan}

\begin{tabular}{|c|c|c|c|}
\hline $\begin{array}{c}\text { Isi Perjanjian } \\
\text { Kawin }\end{array}$ & KUHPerdata & UU Perkawinan & Kompilasi Hukum Islam \\
\hline $\begin{array}{l}\text { Mengatur } \\
\text { tentang } \\
\text { Persatuan Harta } \\
\text { Kekayaan } \\
\text { (Harta Bersama) }\end{array}$ & $\begin{array}{l}\text { Calon suami istri } \\
\text { berhak menyiapkan } \\
\text { beberapa } \\
\text { penyimpangan dari } \\
\text { peraturan } \\
\text { undangundang } \\
\text { sekitar persatuan } \\
\text { harta kekayaan, asal } \\
\text { perjanjian tidak } \\
\text { menyalahi tata } \\
\text { susilaan. (Pasal 139). }\end{array}$ & $\begin{array}{l}\text { Pada waktu atau } \\
\text { sebelum perkawinan } \\
\text { dilangsungkan, } \\
\text { kedua pihak atas } \\
\text { persetujuan bersama } \\
\text { dapat mengadakan } \\
\text { perjanjian tertulis } \\
\text { yang disahkan oleh } \\
\text { Pegawai pencatat } \\
\text { perkawinan (Pasal } \\
\text { 29). }\end{array}$ & $\begin{array}{l}\text { Perjanjian perkawinan } \\
\text { meliputi percampuran harta } \\
\text { pribadi dan pemisahan harta } \\
\text { pencaharian masing-masing } \\
\text { sepanjang hal itu tidak } \\
\text { bertentangan dengan hukum } \\
\text { Islam (Pasal } 47 \text { ayat } 2 \text { ). }\end{array}$ \\
\hline $\begin{array}{l}\text { Perjanjian } \\
\text { dilakukan } \\
\text { sebelum } \\
\text { perkawinan }\end{array}$ & $\begin{array}{l}\text { Atas ancaman } \\
\text { kebatalan, } \\
\text { perjanjian } \\
\text { perkawinan } \\
\text { dibuat dengan akta } \\
\text { notaris sebelum } \\
\text { perkawinan } \\
\text { berlangsung. (Pasal } \\
\text { 47). }\end{array}$ & $\begin{array}{l}\text { Pada waktu atau } \\
\text { sebelum perkawinan } \\
\text { dilangsungkan, } \\
\text { kedua pihak atas } \\
\text { persetujuan bersama } \\
\text { dapat mengadakan } \\
\text { perjanjian tertulis } \\
\text { yang disahkan oleh } \\
\text { Pegawai pencatat } \\
\text { perkawinan.... (Pasal } \\
29 \text { ayat 1). }\end{array}$ & $\begin{array}{l}\text { Pada waktu atau sebelum } \\
\text { perkawinan dilangsungkan } \\
\text { kedua calon mempelai dapat } \\
\text { membuat perjanjian tertulis } \\
\text { yang disahkan Pegawai } \\
\text { Pencatat Nikah mengenai } \\
\text { kedudukan harta dalam } \\
\text { perkawinan. (Pasal } 47 \text { ayat } \\
\text { 1). }\end{array}$ \\
\hline
\end{tabular}




\begin{tabular}{|c|c|c|c|}
\hline $\begin{array}{l}\text { Perjanjian tidak } \\
\text { bertentangan } \\
\text { dengan } \\
\text { kesusilaan, } \\
\text { agama }\end{array}$ & 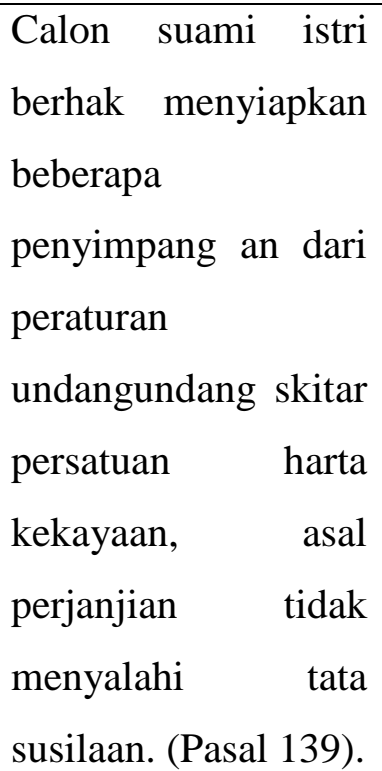 & $\begin{array}{l}\text { Perjanjian } \\
\text { perkawinan tidak } \\
\text { dapat disahkan } \\
\text { bilamana melanggar } \\
\text { batas-batas hukum, } \\
\text { agama, dan } \\
\text { kesusilaan. (Pasal } 29 \\
\text { ayat 2). }\end{array}$ & $\begin{array}{l}\text { Kedua calon mempelai } \\
\text { dapat mengadakan } \\
\text { perjanjian perkawinn dalam } \\
\text { bentuk : } \\
\text { 1. Taklik talak, dan } \\
\text { 2. Perjanjian lain yang tidak } \\
\text { bertentangan dengan hukum } \\
\text { Islam. (Pasal 45). }\end{array}$ \\
\hline
\end{tabular}

Dalam perkawinan, perjanjian perkawinan harus diadakan sebelumnya pernikahan dilangsungkan dan harus diletakkan dalam suatu akta notaris. Selain itu tidak diatur lebih lanjut bagaimana tentang perjanjian perkawinan dimaksud hanya disebutkan bahwa kalau ada perjanjian perkawinan harus dimuat di dalam Akta Perkawinan.(Hutabarat 2008)Perjanjian Perkawinan memberikan perlindungan bagi suami-isteri yang akan terikat dalam suatu perkawinan. Layaknya perjanjian pada umumnya, para pihak yang membuat perjanjian harus mentaati aturan hukum yang melandasi terbentuknya perjanjian tersebut.Para pihak memiliki kebebasan dalam membuat suatu perjanjian, tapi mereka harus tetap terikat pada kaidah, normanorma, kepatutan, ketertiban umum, serta kesusilaan. Selain itu, ketika para pihak sudah terikat dalam suatu perjanjian, maka perjanjian tersebut harus ditaati seperti layaknya para pihak menaati suatu produk Undang-Undang (Hutabarat 2008). Apabila salah satu pihak melakukan wanprestasi atau tidak dapat melaksanakan kewajiban yang telah dicantumkan dalam perjanjian, maka pihak yang dirugikan dapat mengajukan gugatan cerai atau ganti rugi atas kerugian yang telah dideritanya.

Tujuan perjanjian perkawinan :

1. Apabila kekayaan salah satu pihak (suami atau istri) lebih besar dibandingkan harta kekayaan pihak lainnya.

2. Kedua pihak (suami atau istri) membawa masuk harta yang cukup besar ke dalam harta perkawinan.

3. Masing-masing memiliki usaha sendiri. Sehingga apabila salah satu jatuh bangkrut (pailit), maka yang lain tidak ikut pailit. 
4. Terhadap utang-utang yang dibuat sebelum perkawinan masing-masing akan menanggung utangnya masing-masing.(Tunardy 2012)

Pada dasarnya perjanjian perkawinan tidaklah seburuk yang menjadi anggapan masyarakat.Mengingat pentingnya perjanjian perkawinan ternyata cukup banyak manfaatnya bagi suami dan istri. Karena itu manfaat dari Perjanjian Perkawinan adalah dapat mengatur penyelesaian dari masalah yang kira-kira akan timbul selama perkawinan, antara lain :

1. Tentang pemisahan harta kekayaan, jika tidak ada harta gono-gini syaratnya, harus dibuat sebelum pernikahan dan harus dicatatkan di tempat pencatatan perkawinan.

2. Tentang pemisahan hutang, dalam perjanjian perkawinan dapat diatur mengenai masalah hutang yang akan tetap menjadi tanggungan dari pihak yang membawa hutang. Hutang yang dimaksud adalah hutang yang terjadi sebelum pernikahan, selama pernikahan, setelah perceraian bahkan kematian.

3. Tanggung jawab terhadap anak-anak hasil pernikahan tersebut terutama mengenai masalah biaya hidup anak, dan biaya Pendidikannya harus diatur sedemikian rupa berapa besar kontribusi masing-masing orang tua, dalam hal ini tujuannya agar kesejahteraan anak-anak tetap terjamin.(Rini 2008)

Perjanjian kawin dibuat untuk menjaga hubungan, dan citra calon pasangan suami-isteri, juga menghindari tuduhan bahwa salah satu pihak atau keluarganya ingin mendapatkan kekayaan pihak lain, terutama dari hasil pembagian harta gono-gini (harta yang didapat setelah pernikahan).Dibuatnya perjanjian kawin sebelum perkawinan, membawa konsekuensi pada calon pasangan suami isteri yaitu terpisahnya harta masing-masing pihak calon suami-isteri dimana masing-masing berwenang mengurus dan mengusahakan hartanya, sehingga apabila terjadi perceraian di antara calon suami-isteri tersebut kelak maka mengenai harta perkawinan akan diseleaikan sebagaimana diatur dalam perjanjian kawin yang telah dibuat di antara kedua calon suami-isteri tersebut. Salah satu hal yang selalu dipermasalahkan dalam proses perceraian selain masalah pengasuhan anak, pembagian harta gono-gini juga menjadi hal yang sering dipermasalahkan, yang terkadang memakan waktu yang lama dalam menyelesaikannya. Namun apabila ada perjanjian kawin diantara calon pasangan suami istri tersebut, maka hal tersebut tidak akan terjadi karena diselesaikan sesuai dengan kesepakatan dalam perjanjian kawin yang telah dibuat sebelumnya.

Dampak yuridis Perjanjian Perkawinan/Perjanjian Pra Nikah meliputi :

1. Perjanjian mengikat pihak suami dan pihak istri,

2. Perjanjian mengikat pihak ketiga yang berkepentingan, 
3. Perjanjian hanya dapat diubah dengan persetujuan kedua pihak suami dan istri, dan tidak merugikan kepentingan pihak ketiga, serta disahka oleh pegawai pencatat perkawinan.(Abdulkadir 2017)

Berdasarkan latar belakang tersebut penulis tertarik untuk melakukan penelitian dengan judul “Analisis Putusan MA Atas Kasasi Putusan PN.Tuban Nomor 25/Pdt. G/2013/PN. Tuban tentang Perjanjian Perkawinan".Dari uraian di atas maka permasalahan yang dikaji dalam penelitian ini adalah sebagai berikut :

1. Apa latar belakang timbulnya sengketa perjanjian perkawinan dalam putusan MA Atas Kasasi Putusan PN. Tuban Nomor 25/Pdt.G/2013/PN. Tuban?

2. Bagaimana analisisputusan MA Atas Kasasi Putusan PN. Tuban Nomor 25/Pdt.G/2013/PN. Tuban tentang Perjanjian Perkawinan?

Penelitian ini bertujuan untuk mengetahui latar belakang timbulnya sengketa perjanjianperkawinan dalam putusan MA Atas Kasasi Putusan PN. TubanNomor 25/Pdt.G/2013/PN.Tuban serta menganalisis putusan MA Atas Kasasi Putusan PN.TubanNomor 25/Pdt.G/2013/PN.Tuban tentang perjanjian perkawinan.

Mengingat penelitian berfokus pada perjanjian perkawinan sebagaimana sudah pernah dijelaskan, seperti oleh Filma Tamengkel di tahun 2015, penelitian ini berfokus pada Dampak Yuridis Perjanjian Pranikah Ditinjau Dari Undang-Undang Nomor 1 Tahun 1974 tentang Perjanjian Perkawinan.(Tamengkel 2015) Haedah Faradz di tahun 2008, penelitian ini berfokus pada Tujuan dan Manfaat Perjanjian Perkawinan (Haedah Faradz 2008), sertaErdhyan Paramita dan Irnawan Darori di tahun 2017, penelitian ini berfokus pada Akibat Hukum Perjanjian Perkawinan Yang Tidak Disahkan Oleh Pegawai Pencatat Perkawinan (Paramita and Darori 2017).

Maka berdasarkan tulisannya tersebut terdapat perbedaan fokus penelitian yang akan dilakukan penulis dengan penelitian yang sudah ada. Walaupun sama-sama membahas Perjanjian Perkawinan namun penulis menekankan pada analisa yang dilakukan pada putusan MA atas kasasi PN.Tuban Nomor 25/Pdt.G/2013/PN.Tuban mengenai bagaimana latar belakang timbulnya sengketa perjanjian perkawinan dan pertimbangan hakim dalam menjatuhkan putusan atas kasus perjanjian perkawinan.

\section{B. Metode Penelitian}


Di dalam penelitian ini penulis menggunakan jenis penelitianyuridis normatif dengan pendekatan kasus, karena penelitian ini akan mengkonsepsikan hukum sebagai apa yang tertulis dalam peraturan perundang-undangan dengan menganalisis Putusan MA Atas Kasasi Putusan PN. Tuban Nomor 25/Pdt.G/2013/PN.Tuban tentang Perjanjian Perkawinan.

Spesifikasi penelitian ini adalah deskriptif analitis.Deskriptif analitis disini dimaksudkan untuk memberikan gambaran Putusan MA Atas Kasasi Putusan PN.Tuban Nomor 25/Pdt.G/2013/PN.Tuban tentang Perjanjian Perkawinan dikaitkan dengan pelaksanaan hukum positif, yang menyangkut permasalahan yang sedang diteliti, serta memberikan penjelasan dan makna pada pokok permasalahan yang dianalisis sehingga dapat memberikan gambaran yang jelas.

Untuk jenis data yang digunakan dalam penelitian ini adalah data sekunder. Data sekunder tersebut diatas diambil dengan cara studi pustaka dan studi dokumentasi.Data sekunder adalah data yang diperoleh secara tidak langsung, melainkan bersumber dari data-data yang sudah terdokumentasikan dalam bentuk bahan-bahan hukum.(Nazir 2008)Metode analisis data yang digunakan dalam penelitian ini adalah metode analisis-kualitatif. Metode ini berfungsi untuk mempelajari suatu masalah yang ingin diteliti secara mendasar dan mendalam.(Zuriah 2009) Data yang diperoleh dari hasil penelitian diolah dalam tahap analisis, sehingga diperoleh hasil penelitian secara jelas mengenai Putusan MA Atas Kasasi Putusan PN. Tuban Nomor 25/Pdt.G/2013/PN.Tuban tentang Perjanjian Perkawinan.

\section{Hasil Dan Pembahasan}

\section{Latar belakang timbulnya sengketa perjanjian perkawinan dalamputusan MA Atas} Kasasi Putusan PN. Tuban Nomor 25/Pdt.G/2013/PN. Tuban

Perjanjian perkawinan timbul karena adanya suatu perbuatan hukum yang mengatur tentang hubungan yang timbul karena hubungan kekeluargaan yaitu hukum keluarga.(Simanjutak 2017). Hukum tidak menganggap perkawinan sebagai suatu ikatan seumur hidup, perkawinan dapat diputuskan karena perceraian. Dalam suatu perkawinan hubungan antara suami dan istri dapat terjadi adanya suatu perjanjian. (Pringgodigdo 1977). Dalam kasus ini, antara Penggugat dan Tergugat I telah membuat perjanjian kawin sebagaimana yang tertuang dalam Akta Perjanjian Nikah Nomor 200 tertanggal 8 Juli 1994 sebelum kedua belah pihak melangsungkan perkawinan sebagaimana yang diuraikan dalam Kutipan Akta Perkawinan No. 15/130/A/1994 tertanggal 20 Juli 1994. Perjanjian kawin 
antara Penggugat dan Tergugat I dibuat dan ditandatangani di hadapan Turut Tergugat/Notaris di Malang yang mana akta tersebut sebagian isinya dikutip sebagai berikut : Pasal 1 : “diantara suami dan istri tidak akan ada persatuan harta kekayaan juga tidak akan ada persatuan utang dan rugi dan juga tidak akan ada persatuan hasil-hasil dan pendapatanpendapatan dari masing-masing".

Namun, perjanjian kawin yang telah dibuat dan ditandatangani antara Penggugat dan Tergugat I dihadapan Turut Tergugat tidak pernah teregister di Kantor Dinas Kependudukan dan Catatan Sipil maupun didaftarkan di Kantor Kepaniteraan Pengadilan Negeri Tuban sebagaimana mestinya. Pernyataan tersebut tidak sesuai dengan Pasal 29 ayat (1) UndangUndang Nomor 1 Tahun 1974 tentang Perkawinan yang berbunyi : “pada waktu/sebelum perkawinan dilangsungkan, kedua pihak atas perjanjian bersama dapat mengadakan perjanjian tertulis yang disahkan oleh pegawai pencatat perkawinan, setelahmana isinya berlaku juga terhadap pihak ketiga sepanjang pihak ketiga tersangkut". Bentuk dari perjanjian perkawinan tidak ditentukan secara tegas.Hal ini dapat ditafsirkan, dapat dibuat dengan akta otentik atau cukup dibawah tangan. Namun, yang perlu mendapat perhatian meskipun perjanjian perkawinan tersebut dibuat dalam salah satu bentuk di atas, perjanjian perkawinan harus mendapat pengesahan dari Pegawai Pencatat Perkawinan sebagai salah satu syarat sahnya.Akibat hukum perjanjian perkawinan yang tidak mendapat pengesahan dari Pegawai Pencatat Perkawinan adalah batal (nieteg van rechtwege), perjanjian perkawinan tersebut tidak mempunyai kekuatan mengikat secara hukum, sehingga berlakulah prinsip kedudukan harta benda dalam perkawinan (pasal 35 Undangundang Nomor 1 tahun 1974).(Sukardi 2016)

Dari seluruh harta yang diperoleh selama masa perkawinan, ternyata Penggugat tidak bisa menikmati harta-harta yang diperoleh selama perkawinan tersebut, karena seluruh harta bersama yang diperoleh selama perkawinan telah dikuasai oleh Tergugat I. Dalam hal ini Penggugat merasa dirugikan atas perbuatan yang dilakukan oleh Tergugat I.

Oleh karena itu Penggugat mengajukan gugatan ke Pengadilan Negeri Tuban untuk meminta kepada Majelis Hakim membatalkan perjanjian nikah yang telah dibuat antara Penggugat dan Tergugat I karena tidak terpenuhinya syarat sah dilakukannya perjanjian kawin. Selain itu, Penggugat juga mengajukan gugatan untuk meminta kepada Majelis Hakim melakukan sita marital (marital beslag)untuk melindungi harta bersama yang seharusnya menjadi hak Penggugat juga.

Dalam eksepsi, Tergugat I memberikan jawaban atas gugatan yang diajukan Penggugat yakni bahwasanya perjanjian nikah yang telah dibuatnya bersama Penggugat dihadapan 
Turut Tergugat/Notaris di Malang telah didaftarakan pada Kantor Dinas Kependudukan dan Catatan Sipil, sehingga perjanjian nikah yang dibuat bersama dengan Penggugat tidak dapat diganggu gugat, sebagaimana yang diatur dalam Pasal 149 KUH Perdata yang menyebutkan, "setelah perkawinan berlangsung, perjanjian perkawinan dengan cara bagaimana tidak boleh dirubah”. Dan Pasal 29 ayat 4 Undang-Undang Nomor 1 Tahun 1974 tentang Perkawinan yang menyebutkan, "selama perkawinan dilangsungkan perjanjian tersebut tidak dapat diubah, keculai bila dari kedua belah pihak ada persetujuan untuk mengubah dan perubahan tidak merugikan pihak ketiga". Selain itu, berdasarkan Pasal 29 ayat 3 Undang-Undang Nomor 1 Tahun 1974 tentang Perkawinan juga mneyebutkan, "perjanjian tersebut berlaku sejak perkawinan dilangsungkan".

Dengan begitu, Tergugat I menyatakan, harta yang teratasnamakan Tergugat I dengan adanya perjanjian nikah yang dibuat oleh Penggugat dan Tergugat I sebelum dilangsungkannya perkawinan, maka harta tersebut menjadi milik Tergugat I dan tidak dapat diganggu gugat oleh Penggugat atau siapapun. Berdasarkan uraian di atas, terlihat bahwa perjanjian perkawinan yang dibuat antara Penggugat dan Tergugat I, tidak sesuai dengan ketentuan Pasal 147 jo. Pasal 152 KUH Perdata.(Kitab Undang-Undang Hukum Perdata, n.d.)

Pasal 147 KUH Perdata :

"Perjanjian kawin harus dibuat dengan akta notaris sebelum pernikahan berlangsung, dan akan menjadi batal bila tidak dibuat secara demikian. Perjanjian itu akan mulai berlaku pada saat pernikahan dilangsungkan, tidak boleh ditentukan saat lain untuk itu”.

Pasal 152 KUH Perdata :

Ketentuan yang tercantum dalam perjanjian kawin, yang menyimpang dari persatuan menurut undang-undang, seluruhnya atau sebagian, tidak akan berlaku bagi pihak ketiga sebelum hari ketentuan-ketentuan itu dibuktikan dalam suatu register umum yang harus diselenggarakan untuk itu di kepaniteraan pada Pengadilan Negeri, yang di daerah hukumnya perkawinan itu dilagsungkan, atau kepaniteraan di mana akta perkawinan itu didaftarkan, jika perkawinan berlangsung di luar negeri.

Selain itu, hal yang dikaitkan dalam perkara ini adalah masa berakhirnya suatu perjanjian kawin tersebut, tidak ada peraturan perundangan apapun yang mengatur dan menjelaskan tentang kapan dan bagaimana berakhirnya perjanjian kawin tersebut, sehingga perjanjian kawin antara Penggugat dan Tergugat I bersifat kabur.

Oleh karena itu, jelas adanya dalam putusan MA Atas Kasasi Putusan PN. Tuban Nomor 25/Pdt.G/2013/PN. Tuban telah terjadi sengketa mengenai perjanjian perkawinan 
antara Penggugat dan Tergugat I, suami sebagai Penggugat dan istri sebagai Tergugat I. Dalam putusan MA Atas Kasasi Putusan PN. Tuban Nomor 25/Pdt. G/2013/PN. Tuban tentang Perjanjian Perkawinan, Penggugat mengajukan gugatan terhadap Tergugat I.

Apabila terjadi sengketa antara suami dan istri mengenai perjanjian perkawinan, maka salah satunya dapat mengajukan perkaranya ke pengadilan dengan membuat gugatan. Pengertian gugatan itu sendiri menurut Hukum Acara Perdata pada Pasal 1 angka 2, gugatan adalah tuntutan hak yang mengandung sengketa dan diajukan ke pengadilan untuk mendapatkan putusan.(Tim Visi Yustisia 2015)Tujuan para pihak menempuh proses perkara di pengadilan adalah untuk mendapatkan penetuan bagaimana hukumnya atas suatu perkara, yaitu bagaimana hubungan hukum di antara para pihak yang berperkara dan segala apa yang telah diputuskan dapat dijalankan. Jadi hasil yang diharapkan para pihak adalah agar segala hak dan kewajiban yang telah diberikan dalam hukum materiil, baik yang berupa hukum tertulis maupun yang tidak tertulis dapat diwujudkan lewat pengadilan. (Sunarto 2015)

\section{Analisis Putusan MA Atas Kasasi Putusan PN. Tuban Nomor 25/Pdt.G/2013/PN.} Tuban tentang Perjanjian Perkawinan

Isi putusan MA atas kasasi putusan PN.Tuban Nomor 25/Pdt. G/2013/PN. Tuban tentang Perjanjian Perkawinan adalah sebagai berikut :

a. Dalam Eksepsi : Menolak eksepsi Tergugat I untuk seluruhnya ;

b. Dalam Pokok Perkara :

1) Mengabulkan gugatan Penggugat untuk sebagian;

2) Menyatakan batal Perjanjian Nikah Nomor 200 tertanggal 8 Juli 1994 dibuat dan di tandatangani di hadapan Turut Tergugat/Notaris di Malang, dengan segala akibat hukumnya;

3) Menyatakan seluruh harta yang diperoleh selama perkawinan antara Penggugat dengan Tergugat I menjadikan harta bersama Penggugat dan Tergugat I;

4) Menghukum Tergugat I untuk membagi harta bersama yang diperoleh selama perkawinan;

5) Penggugat dan Tergugat I yang besarnya sama rata antara Penggugat dan Tergugat I ; sita atas harta bersama yang diperoleh selama perkawinan Penggugat dan Tergugat I (marital beslag) yang telah diletakkan oleh Pengadilan Negeri Tuban sah dan berharga;

6) Menghukum Tergugat I, Tergugat II dan Turut Tergugat untuk tunduk pada putusan ini; 
7) Menghukum Tergugat I, Tergugat II dan Turut Tergugat untuk membayar biaya perkara yang sampai saat ini ditetapkan sebesar Rp.1.172.000,- (satu juta seratus tujuh puluh dua ribu rupiah);

8) Menolak gugatan penggugat untuk selain dan selebihnya;

Dari uraian Putusan MA atas kasasi putusan PN. Tuban Nomor 25/Pdt.G/2013/PN.Tuban tersebut di atas, dapat dilakukan analisis secara keseluruhan terkait dengan permasalahan mengenai perjanjian perkawinan dalam Putusan MA atas kasasi putusan PN.Tuban Nomor 25/Pdt.G/2013/PN.Tuban, yaitu dalam mengkaji perjanjian perkawinan dalam putusan ini, dasar diajukannya gugatan dalam putusan MA atas kasasi putusan PN.Tuban Nomor 25/Pdt. G/2013/PN. Tuban adalah Penggugat merasa dirugikan atas perjanjian nikah yang dilakukan bersama dengan Tergugat I. Penggugat mengajukan gugatan kepada Majelis Hakim untuk membatalkan perjanjian perkawinan yang telah di buat kedua belah pihak pada saat melakukan perkawinan karena perjanjian perkawinan tersebut tidak pernah teregister di Kantor Kependudukan dan Catatan Sipil Kabupaten Tuban dan didaftarkan ke Kepaniteraan Pengadilan Negeri Tuban. Penggugat memohon kepada Majelis Hakim untuk melakukan sita marital atas harta yang di kuasai oleh Tergugat I karena seharusnya harta tersebut menjadi harta bersama.

Selanjutnya untuk menjamin tidak beralihnya harta bersama tersebut, Penggugat meminta Majelis Hakim untuk mengeluarkan penetapan sita marital dan pemblokiran atas harta bersama tersebut. Bahwa ketentuan hukum yang berlaku telah menyebutkan bahwa harta bersama haruslah dibagi dua seimbang antara suami dan istri dan dalam perkara aquo haruslah dibagi sama rata antara Penggugat dan Tergugat I. Keputusan Majelis Hakim disesuaikan dengan peraturan perundangan yang berlaku, khususnya pasal-pasal pada KUHPerdata, adat, dan kebiasaan serta praktek yang berlaku dan berkaitan dalam perkara aquo, aturan hukum dan peraturan perundang-undangan yang terkait dengan perkara ini.

Menurut peneliti, jika mengacu pada alasan diajukannya gugatan dalam putusan MA atas kasasi putusan PN.Tuban Nomor 25/Pdt. G/2013/PN.Tuban tersebut di atas oleh Penggugat adalah sudah tepat.Peneliti juga berpendapat bahwa putusan yang di ambil Majelis Hakim pun juga sudah benar.Dalam mengajukan gugatannya Penggugat juga berhak untuk menentukan siapa saja yang dapat dijadikan Tergugat, berdasarkan Yurisprudensi Mahkamah Agung Nomor 305/K Sip/1991 yang menyatakan "bahwa penggugat mempunyai kebebasan untuk memilih siapa-siapa yang dinyatakan sebagai tergugat".Dalam putusan MA atas kasasi putusan PN.Tuban Nomor 25/Pdt. G/2013/PN.Tuban, Penggugat menetapkan 3 (tiga) orang sebagai Tergugat. 
Selanjutnya atas gugatan Penggugat, pada hari sidang yang sudah ditentukan Tergugat I, Tergugat II telah hadir dan memaparkan jawaban atas gugatan Penggugat. Sedangkan Turut Tergugat tidak pernah hadir dalam persidangan dan tanpa alasan yang sah.Dengan begitu, peneliti menyimpulkan bahwasanya Majelis Hakim dalam mempertimbangkan perkara ini, yaitu perjanjian nikah yang Penggugat dan Tergugat I buat dan tandatangani di hadapan Turut Tergugat adalah perjanjian nikah "akal-akalan", karena Penggugat dan Tergugat I tidak bersungguh-sungguh dalam untuk melaksanakan perjanjian kawin tersebut.Para pihak pun tidak melakukan pula dengan sebenarnya, karena tidak ada dalam berita acara pencatatan perkawinan dan tidak dicatat dalam akta perkawinan bahwa dalam perkawinan Penggugat dan Tergugat I terdapat perjanjian kawin.Perjanjian kawin antara Penggugat dan Tergugat I juga tidak memenuhi syarat formil dan materiil dalam pelaksanaannya. Sehingga perjanjian kawin tersebut tidak sah dan dikatakan batal demi hukum.

Demikianlah beberapa dasar dan analisis dalam pertimbangan hakim pada putusan MA atas kasasi putusan PN.Tuban Nomor 25/Pdt.G/2013/PN.Tuban tentang Perjanjian Perkawinan. Pada prinsipnya pertimbangan hakim dalam menjatuhkan putusan pada gugatan mengenai harta bersama, mengacu pada dasar hukum gugatan Penggugat serta jawaban Tergugat I maupun Tergugat II, dengan mempertimbangkan terlebih dahulu bukti-bukti yang diajukan Penggugat, Tergugat I, dan Tergugat II melalui proses pembuktian di persidangan. Pembuktian dalam konteks ini dilakukan untuk bukan berdasar pada dugaan atau kesimpulan dari gugatan maupun jawaban, tetapi dijadikan bukti adanya kebenaran/fakta dalam perkara ini.

\section{Simpulan}

Latar belakang timbulnya sengketa dalam putusan MA atas kasasi putusan PN.Tuban Nomor 25/Pdt. G/2013/PN.Tuban tentang perjanjian perkawinan dikarenakan perjanjian perkawinan yang telah dibuat antara Penggugat dan Tergugat I sebenarnya tidak pernah teregister di Kantor Dinas Kependudukan Catatan Sipil maupun didaftarkan di Kantor Kepaniteraan Pengadilan Negeri, sehingga perjanjian perkawinan tersebut tidak sah.Namun harta yang seharusnya menjadi harta bersama antara Penggugat dan Tergugat I telah dikuasai oleh Tergugat I. Dalam hal ini, Penggugat merasa dirugikan atas perbuatan Tergugat I, sehingga Penggugat mengajukan gugatan untuk membatalkan perjanjian perkawinan yang Penggugat dan Tergugat I telah buat, serta mengajukan sita marital atas harta yang berada pada Tergugat I. 
Putusan MA atas kasasi putusan PN.Tuban Nomor 25/Pdt.G/2013/PN. Tuban tentang perjanjian perkawinan, dalam Eksepsi, menolak Eksepsi Tergugat I untuk seluruhnya dikarenakan berdasarkan jawaban Tergugat I yang meminta kepada Majelis Hakim untuk menolak seluruh gugatan yang diajukan Penggugat tidak dapat dikabulkan, dikarenakan perjanjian perkawinan yang dibuat dan ditandatangani antara Penggugat dan Terggugat I tidak memenuhi syarat formil sehingga menyebabkan perjanjian kawin tersebut batal demi hukum dan tidak sah.Sedangkan dalam pokok perkara, Majelis Hakim mengabulkan gugatan Penggugat untuk sebagian, menyatakan batalnya Perjanjian Nikah yang dibuat dan ditandatangani di hadapan Turut Tergugat/Notaris di Malang, dengan segala akibat hukumnya, dikarenakan Perjanjian Nikah yang dilakukan Penggugat dan Tergugat I tidak pernah teregister di Kantor Kependudukan dan Catatan Sipil dan terdaftar pada Kantor Kepaniteraan Pengadilan Negeri. Serta menyatakan seluruh harta yang diperoleh selama perkawinan antara Penggugat dengan Tergugat I dijadikan sebagai harta bersamaserta menghukum Tergugat I untuk membagi harta bersama yang diperoleh selama perkawinan Penggugat dan Tergugat I yang besarnya sama rata antara Penggugat dan Tergugat I, dengan alasan bahwa Perjanjian Nikah yang telah dibuat tersebut tidaklah berlaku. Dengan begitu, dapat dikatakan perjanjian nikah yang Penggugat dan Tergugat I adalah perjanjian nikah "akal-akalan", karena Penggugat dan Tergugat I tidak bersungguh-sungguh dalam untuk melaksanakan perjanjian kawin tersebut.Para pihak pun tidak melakukan pula dengan sebenarnya, karena tidak ada dalam berita acara pencatatan perkawinan dan tidak dicatat dalam akta perkawinan bahwa dalam perkawinan Penggugat dan Tergugat I terdapat perjanjian kawin.

\section{DAFTAR PUSTAKA}

Abdulkadir, Muhammad. (2017). Hukum Perdata Indonesia. Catakan II. Bandung: $\quad$ PT. CitraAditya Bakti.

Azzam, Ummu. (2012). Walimah Cinta, Mengadakan Pernikahan Itu Mudah \& Berkah. Jakarta: Agromedia Pustaka.

Hutabarat, Samuel. (2008). Penawaran Dan Penerimaan Dalam Hukum Perjanjian. Jakarta: Grasindo.

Jehani, Libertus. (2008). Perkawinan, Apa Resiko Hukumnya? Jakarta: Forum Sahabat.

Manjorang, Aditya P., and Intan Aditya. 2015. The Law of Love: Hukum Seputar Pranikah,

Pernikahan, Dan Perceraian Di Indonesia. Pertama. Jakarta: Transmedia Pustaka.

Nazir, Moch. (2008). Metode Penelitian. Jakarta: Ghalia Indonesia.

Pringgodigdo. (1977). Ensiklopedi Umum. II. Yogyakarta: Kanisius. 
Simanjutak. (2017). Hukum Perdata Indonesia. III. Jakarta: Kencana.

Sunarto. (2015). Peran Aktif Hakim Dalam Hukum Perdata. Jakarta: Prenadamedia $\quad$ Group.

Tim Visi Yustisia. (2015). KUHPerdata Dan KUHAPerdata. Jakarta: Visimedia.

Yuliartha, Erike. (2007). The Wedding Book. Pertama. Jakarta: Transmedia.

Zuriah, Nurul. (2009). Metodologi Penelitian Sosial Dan Pendidikan. Jakarta: Bumi Aksara.

Arief, Hanafi. (2017). "Perjanjuan Dalam Perkawinan (Sebuah Telaah Terhadap Hukum Positif Di Indonesia)" IX.

Haedah Faradz. (2008). “Tujuan Dan Manfaat Perjanjian Perkawinan.” Dinamika Hukum 8.

Paramita, Erdhyan, and Irnawan Darori. (2017). “Akibat Hukum Perjanjian Perkawinan Yang

Tidak Disahkan Oleh Pegawai Pencatat Perkawinan.” Repertorium IV.

Rini, Mike. (2008). "Perlukah Perjanjain Pranikah.” Dinamika Hukum 8.

Sukardi. (2016). “Kajian Yuridis Perjanjian Perkawinan Menurut Kitab Undang-Undang Hukum

Perdata, Undang-Undang Nomor 1 Tahun 1974 Dan Kompilasi Hukum Islam.”

Khatulistiwa VI.

Susanti, Dyah Ochtorina. (2018). "Perjanjian Kawin Sebagai Bentuk PerlindunganHukum Bagi Pasangan Suami Istri” I.

Tamengkel, Filma. (2015). “Dampak Yuridis Perjanjian Pranikah Ditinjau Dari Undang- Undang Nomor 1 Tahun 1974 Tentang Perjanjian Perkawinan.” Lex Privatum III.

Silviana. (2013). “Pisah Harta, Mungkinkah?” Tabloid, 2013.

Tunardy, Wibowo T. (2012). “Perjanjian Kawin.” 2012.(Diakses tanggal 26 Februari 2020) http://www.jurnalhukum.com/perjanjian-kawin-huwdlijkse-voorwaarden/.

Instruksi Presiden. 1991.

Keputusan Menteri Agama. 1991.

Kitab Undang-Undang Hukum Perdata. n.d.

Undang-Undang Dasar Negara Republik Indonesia Tahun 1945. n.d.

Undang-Undang Perkawinan. 1974. 